\title{
Aspergillus-fermented Jatropha curcas seed cake: proximate composition and effects on biochemical indices in Wistar rats
}

\author{
SULAIMAN ADENIKE FAOZIYAT ${ }^{1}$, AHMED EL-IMAM MUSTAPHA AMINA², AFEEZ \\ ADEYEMI ADEYEMO ${ }^{1}$, RIHANAT BUKOLA MUHAMMED ${ }^{1}$, ABIODUN MUINAT SULAIMAN ${ }^{1}$, \\ ABDULFATTAH ORELOPE ALIYU ${ }^{2}$ and OLUYOMI STEPHEN ADEYEMI ${ }^{3}$ \\ ${ }^{1}$ Department of Biochemistry, Faculty of Life Sciences, University of Ilorin, \\ P.M.B. 1515, Ilorin, Nigeria \\ ${ }^{2}$ Department of Microbiology, Faculty of Life Sciences, University of Ilorin, \\ P.M.B. 1515, Ilorin, Nigeria \\ ${ }^{3}$ Department of Biological Sciences, Landmark University, Omu-Aran, Nigeria
}

Corresponding author: Adeyemi Oluyomi Stephen, adeyemi.oluyomi@1mu.edu.ng,yomibowa@yahoo.com

(Received on 18 November 2013; Accepted on 23 September 2014)

\begin{abstract}
This study evaluated Jatropha curcas seed cake fermented by Aspergillus niger for use as a potential source of protein in animal feed production. Wistar rats were randomly assigned to 4 groups (A-D, of 3 rats each) and fed different protein-rich diets for 4 weeks. Group 1 (control) was fed with soybean as a protein source, while Groups 2, 3, and 4 were given feeds supplemented instead with Aspergillus-fermented $J$. curcas, unfermented J. curcas, and a mix of Aspergillus-fermented J. curcas and soybean (1:1), respectively. At the end of the experiment, rats were sacrificed, and their serum and vital organs were harvested for further analyses. Proximate analyses of the various diet combinations showed significant $(P<0.05)$ variations in crude protein, crude fibre, ether extract, and ash content. Enzyme assays (alanine transaminase, aspartate transaminase, and alkaline phosphatase) in rat serum and tissue homogenates indicate that the detoxification of $J$. curcas kernel cake by A. niger fermentation is viable and promising. Body weight generally did not differ significantly between the groups, but all rats put on weight in week 1 (Group 2 most strongly). The initial weight gain was followed by a slight decreasing trend in all groups in weeks 2-4, probably due to an adaptation mechanism. One rat fed with the unfermented cake (Group 3) died in week 2, confirming that the cake is not safe for direct consumption until it is processed. Our data support further use of Aspergillus-fermented J. curcas as an alternative protein source in animal feed preparation.
\end{abstract}

Keywords: protein, animal feeds, nutrition, solid state fermentation

\section{INTRODUCTION}

The global population is growing and there is an urgent need to increase animal production in order to meet the rising demand for animal protein. The consumption of conventional feedstuffs, like soybean, maize, sorghum, etc., by humans may 
undermine their availability to animals, so the possibility of raising animals on unconventional but easily available feedstuffs in the tropics and subtropics deserves more attention (BELEwU et al. 2009a, b).

An example is the seed of Jatropha curcas (commonly known as physic nut, Barbados nut or purging nut), which belongs to the family Euphorbiaceae. Jatropha is an oilseed plant with well-known medicinal properties (MAKKAR et al. 1998; GALLEGOSTINTORE et al. 2011). It grows quickly and survives in poor stony soils, is resistant to drought and diseases, reaches the height of 3-8 m, and can be grown on wastelands or barren and marginal agricultural lands, where no irrigation facilities are available. Thus it does not compete with conventional feed crops for land and water (MAKKAR et al. 1997; DeVENDRA et al. 2004).

Jatropha grows abundantly in Nigeria. Currently several research institutions in this country, including the University of Ilorin where the present work was carried out, have dedicated thousands of hectares to the cultivation of Jatropha. This underscores the increasing research efforts aimed at exploiting the full potentials of the plant. In Nigeria, the high cost of animal feed drives the motivation to find an alternative source of protein for livestock animals from waste agricultural residues and under-utilized plant materials, like Jatropha curcas seed.

This species is a small shrub or tree, which does not require much care and has a lifespan of 30-50 years. The plant deserves attention for its merits. The seed cake remaining after extracting the oil (either mechanically or chemically) was found to be rich in protein (AdERIBIGBE et al. 1997; MAKKAR \& BECKER 1999). However, Jatropha curcas contains some toxins and anti-nutrients, such as cyanide, saponin, tannin, phytate, etc.

Various methods of seed detoxification (BELEwU \& SAm 2010; Belewu et al. 2010) physical, mechanical, and chemical are well documented in literature (ADERIBIGBE et al. 1997; MAKKAR \& BECKER 1999). The biological method of detoxification involving a cocktail of fungi seems promising (PeAce \& Aladesanmi 2008; Belewu et al. 2010). Previous successful detoxification of the Jatropha cake by BELEWU \& SAM (2010) and BELEWU et al. (2010) inspired us to conduct the present study.

This study is an attempt to determine whether Aspergillus-fermented Jatropha curcas can serve as an alternative to soybean in animal feeds. For this purpose, we have assessed its proximate composition and evaluated its effect on body weight, organ: body weight ratio, and some biochemical parameters in Wistar rats.

\section{MATERIAL AND METHODS}

\section{Experimental animals}

Twelve rats of Wistar strain (average weight about $200 \mathrm{~g}$ ) were used in the study. The animals were obtained from the small Animal Unit in the Department of Biochemistry, University of Ilorin, Nigeria. The rats were housed in a well-ventilated and hygienic environment and acclimatized for 14 days before the experiment. Rats had free access to clean water and feed ad libitum. Handling of experimental animals was consistent with the ethical guidelines as approved by the University of Ilorin Ethics Committee, for scientific and medical research. 


\section{Reagents}

All reagents were of analytical grade and prepared with distilled water unless otherwise stated.

\section{Fungal culture}

Aspergillus niger culture was obtained from the Department of Microbiology, University of Ilorin, Ilorin. The organism was subcultured on potato dextrose agar (PDA) plates, amended with $0.1 \%$ streptomycin to suppress bacterial growth, and incubated at room temperature for 7 days (FAwOLE \& Oso 1995). The organism was next stored in PDA slants at $4^{\circ} \mathrm{C}$.

\section{Solid state fermentation of Jatropha curcas kernel cake}

Dried mature seeds of $J$. curcas were obtained from Oyo State, in South-West Nigeria, and a sample was deposited in the University herbarium. The seeds were cracked open by using a mortar and pestle and cleaned. The kernels obtained were milled using an industrial seed-mill and the oil was extracted using a hydraulic press. The cake was sun-dried for 3 days, and then stored at room temperature. Prior to fermentation, a known quantity of cake was measured into glass bottles and moistened to about $75 \%$ $\mathrm{v} / \mathrm{w}$ with distilled water, then sterilized at $121^{\circ} \mathrm{C}$ for $15 \mathrm{~min}$. The sterilized cake was left to cool and aseptically inoculated with spores of Aspergillus niger by washing a medium Petri dish covered with $A$. niger spores with sterile $0.5 \%$ Tween solution and a bent glass rod. The inoculated substrate was then incubated at room temperature for 7 days, by which time the fungi had colonized the cake. Next, the growth was terminated by oven drying at $70{ }^{\circ} \mathrm{C}$ overnight and then it was used to supplement the feed.

\section{Animal grouping and feed formulation}

The rats were randomly assigned to 4 groups and fed for 4 weeks with diets supplemented as follows: Group 1 (the control) with added soybean, Group 2 with added fermented $J$. curcas, Group 3 with added unfermented $J$. curcas, and Group 4 with an added mix (1:1) of fermented $J$. curcas and soybean (Table 1).

Table 1. Formulation of feeds used in the experiment

\begin{tabular}{lrrrr}
\hline \multirow{2}{*}{ Component } & \multicolumn{4}{c}{ Content $(\%, \mathrm{w} / \mathrm{w})$ in feeds for groups $1-4$} \\
\cline { 2 - 5 } & 1 & 2 & 3 & 4 \\
\hline Corn starch & 50.6 & 50.6 & 50.6 & 50.6 \\
Soybean & 25.0 & - & - & 12.5 \\
Fermented Jatropha cake & - & 25.0 & - & 12.5 \\
Unfermented Jatropha cake & - & - & 25.0 & - \\
Sucrose & 10.0 & 10.0 & 10.0 & 10.0 \\
Soybean oil & 5.0 & 5.0 & 5.0 & 5.0 \\
Vitamin/mineral mix & 5.0 & 5.0 & 5.0 & 5.0 \\
Cellulose & 4.0 & 4.0 & 4.0 & 4.0 \\
D-methionine & 0.4 & 10.0 & 10.0 & 10.0 \\
\hline
\end{tabular}




\section{Determination of proximate composition}

Protein content, crude fat and fibre, moisture content as well as carbohydrate and ash content were determined following established protocols described by the Association of Official Analytical Chemists (AOAC 1995).

\section{Preparation of serum and tissue homogenates}

Following cessation of treatments, rats were sacrificed under anaesthesia. The blood was collected into a clean centrifuge tube and centrifuged (Heraeus Labofuge 300, Thermo Scientific, Hampshire, UK) at $4000 \mathrm{~g}$ for $10 \mathrm{~min}$ to yield the serum. The heart, kidneys, and liver were harvested, weighed, and homogenized using a Teflon homogenizer (Sigma-Aldrich Chemie $\mathrm{GmbH}$, Munich, Germany) in 5 volumes of cold $0.25 \mathrm{M}$ sucrose solution. The tissue homogenates were centrifuged (Heraeus Labofuge 300, Thermo Scientific, Hampshire, UK) at $5000 \mathrm{~g}$ for $10 \mathrm{~min}$ to remove particulates. The serum and tissue homogenates were next used for biochemical analyses.

\section{Biochemical assays}

Activities of alanine transaminase (EC 2.6.1.2, ALT), aspartate transaminase (EC 2.6.1.1, AST), and alkaline phosphatase (EC 3.1.3.1, ALP) were assayed using Randox assay kits (Reitman \& Frenkel 1957; Schmidt \& Schmidt 1963; Rec GSCC 1972). Assays were carried out using a spectrophotometer (Shimadzu, Japan).

\section{Statistical analysis}

Data were analysed on Graphpad Prism 3 (GraphPad Software Inc., San Diego, CA) using one-way analysis of variance (ANOVA) and post-hoc Tukey test. Data are reported as mean value \pm standard error of the mean $(\mathrm{SE})$. Differences at $P<0.05$ are considered significant.

\section{RESULTS}

To explore the use of $J$. curcas as a diet supplement for animals, the Jatropha seed cake was detoxified by fermentation (with the fungus Aspergillus niger) and next fed to rats for biochemical evaluation. There was a significant increase in moisture content of the feed with fermented $J$. curcas as compared to the control feed (with soybean). Besides, the feed with fermented J. curcas had lower contents of ash, protein, fat, fibre and dry matter than the feed with unfermented J. curcas. In contrast, the feed with fermented Jatropha had higher levels of protein and fibre than the control diet. Also the combined diet supplemented with both soybean and fermented Jatropha had elevated contents of protein and fibre, relative to the control (Table 2).

Diets supplemented with fermented and unfermented $J$. curcas caused an increase in body weight of the animals, relative to the control and combined groups, but differences between groups were not significant (Table 3). By the end of the experiment, the diet with fermented $J$. curcas yielded the highest, although not significant, weight gain in the animals. There were no significant variations in the organ: body weight ratio between the groups (Fig. 1). 


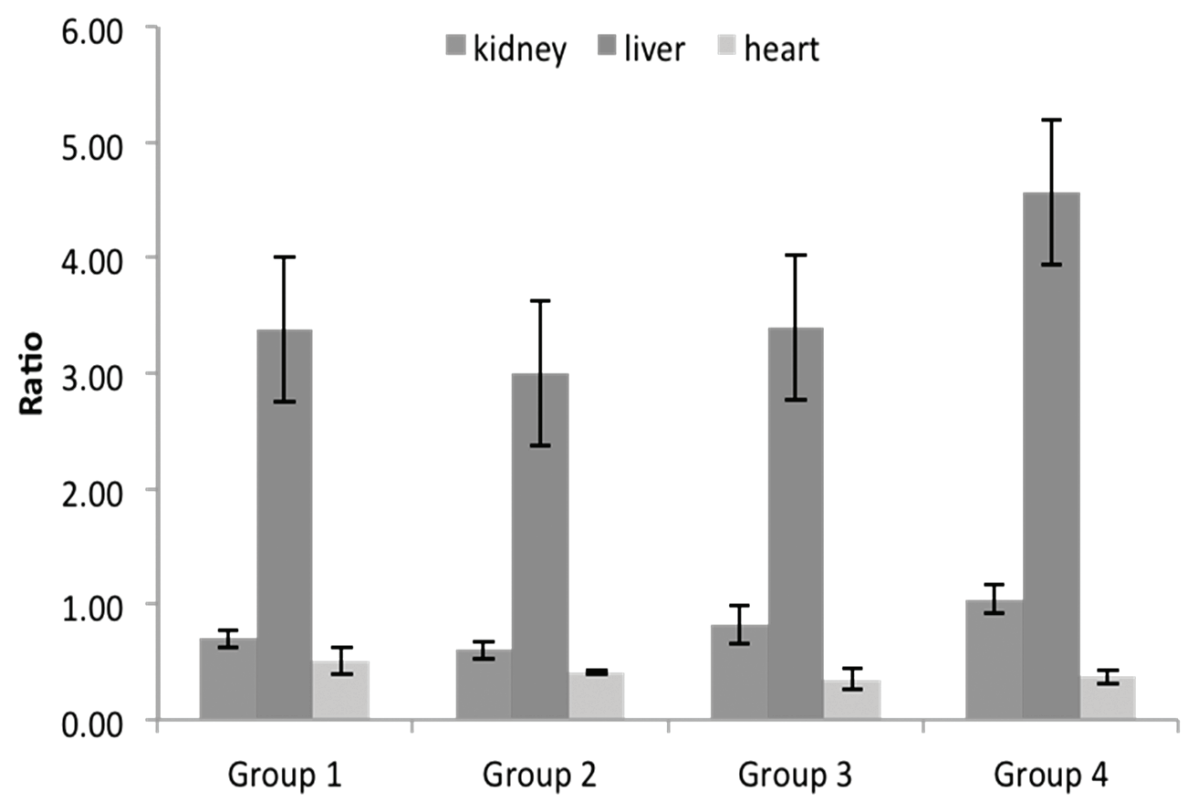

Fig. 1. Organ: body weight ratio of rats fed with different feeds: Group $1=$ with soybean supplement; Group 2 = with fermented $J$. curcas supplement; Group 3 = with unfermented $J$. curcas supplement; Group $4=$ with fermented $J$. curcas and soybean supplements (1:1). Data are means $\pm \mathrm{SE}(n=3)$

Table 2. Proximate composition of the tested animal feeds

\begin{tabular}{lrrrr}
\hline & \multicolumn{4}{c}{ Mean content $(\%, w / w)$ in feeds for groups 1-4 } \\
\cline { 2 - 5 } Component & 1 & 2 & 3 & 4 \\
\hline Moisture & $7.36^{\mathrm{a}}$ & $7.64^{\mathrm{b}}$ & $7.29^{\mathrm{a}}$ & $7.72^{\mathrm{c}}$ \\
Ash & $5.01^{\mathrm{a}}$ & $5.57^{\mathrm{b}}$ & $6.97^{\mathrm{c}}$ & $5.05^{\mathrm{a}}$ \\
Protein & $7.31^{\mathrm{a}}$ & $9.83^{\mathrm{b}}$ & $13.55^{\mathrm{d}}$ & $11.29^{\mathrm{c}}$ \\
Fat & $15.44^{\mathrm{a}}$ & $10.86^{\mathrm{c}}$ & $14.27^{\mathrm{a}}$ & $13.49^{\mathrm{b}}$ \\
Fibre & $2.18^{\mathrm{a}}$ & $8.11^{\mathrm{c}}$ & $11.21^{\mathrm{d}}$ & $4.69^{\mathrm{b}}$ \\
Dry matter & $92.62^{\mathrm{a}}$ & $92.36^{\mathrm{b}}$ & $92.72^{\mathrm{a}}$ & $92.28^{\mathrm{b}}$ \\
Carbohydrate & $62.70^{\mathrm{a}}$ & $57.99^{\mathrm{b}}$ & $46.71^{\mathrm{c}}$ & $57.76^{\mathrm{b}}$ \\
\hline
\end{tabular}

Group 1 = with soybean supplement; Group 2 = with fermented $J$. curcas supplement; Group 3 = with unfermented $J$. curcas supplement; Group $4=$ with fermented $J$. curcas and soybean supplements (1:1). Values with different superscripts in the same row significantly differ at $P<0.05$. 
Table 3. Mean weight $(\mathrm{g})$ of experimental rats following exposure to various feed supplements

\begin{tabular}{lcccc}
\hline & \multicolumn{4}{c}{ Mean body weight \pm SE $(\mathrm{g})$ in groups $1-4$} \\
\cline { 2 - 5 } Week & 1 & 2 & $3^{*}$ & 4 \\
\hline 0 & $147.0 \pm 14.94^{\mathrm{a}}$ & $140.5 \pm 13.20^{\mathrm{a}}$ & $125.1 \pm 9.84^{\mathrm{a}}$ & $133.8 \pm 2.88^{\mathrm{a}}$ \\
1 & $159.6 \pm 2.54^{\mathrm{b}}$ & $234.9 \pm 5.68^{\mathrm{b}}$ & $212.2 \pm 7.58^{\mathrm{b}}$ & $159.6 \pm 2.28^{\mathrm{b}}$ \\
2 & $154.5 \pm 3.56^{\mathrm{c}}$ & $225.7 \pm 3.84^{\mathrm{c}}$ & $192.7 \pm 3.90^{\mathrm{c}}$ & $152.7 \pm 0.90^{\mathrm{c}}$ \\
3 & $151.4 \pm 4.18^{\mathrm{c}}$ & $218.1 \pm 2.32^{\mathrm{d}}$ & $176.3 \pm 0.40^{\mathrm{d}}$ & $148.8 \pm 0.12^{\mathrm{d}}$ \\
4 & $149.0 \pm 4.66^{\mathrm{d}}$ & $213.1 \pm 1.32^{\mathrm{d}}$ & $165.2 \pm 1.82^{\mathrm{d}}$ & $146.3 \pm 0.38^{\mathrm{d}}$ \\
\hline
\end{tabular}

Group 1 = with soybean supplement; Group 2 = with fermented $J$. curcas supplement; Group 3 = with unfermented $J$. curcas supplement; Group $4=$ with fermented $J$. curcas and soybean supplements (1:1). Values are means $\pm \mathrm{SE}(n=3)$. Values with different superscripts in the same row significantly differ at $P<0.05 . *$ One rat in Group 3 died in the second week, so the means in weeks 3-4 are based on measurements of the other 2 animals.

Table 4. Alanine transaminase (ALT) levels in rat serum and tissues following exposure to various feed supplements

\begin{tabular}{lcccc}
\hline & \multicolumn{4}{c}{ ALT activity (U/I) in serum and tissues } \\
\cline { 2 - 5 } Group & serum & kidney & liver & heart \\
\hline 1 & $8.00 \pm 2.56^{\mathrm{a}}$ & $22.67 \pm 10.17^{\mathrm{a}}$ & $10.00 \pm 9.00^{\mathrm{a}}$ & $27.00 \pm \mathrm{s} 7.51^{\mathrm{a}}$ \\
2 & $4.33 \pm 1.76^{\mathrm{b}}$ & $37.67 \pm 18.32^{\mathrm{c}}$ & $7.33 \pm 3.18^{\mathrm{c}}$ & $36.33 \pm 3.48^{\mathrm{c}}$ \\
3 & $2.33 \pm 0.88^{\mathrm{c}}$ & $38.00 \pm 28.29^{\mathrm{c}}$ & $45.00 \pm 19.31^{\mathrm{b}}$ & $47.67 \pm 24.84^{\mathrm{c}}$ \\
4 & $4.00 \pm 2.52^{\mathrm{b}}$ & $33.33 \pm 18.32^{\mathrm{b}}$ & $52.00 \pm 13.00^{\mathrm{b}}$ & $19.67 \pm 6.57^{\mathrm{b}}$ \\
\hline
\end{tabular}

Group 1 = with soybean supplement; Group 2 = with fermented $J$. curcas supplement; Group 3 = with unfermented $J$. curcas supplement; Group $4=$ with fermented $J$. curcas and soybean supplements (1:1). Values are means $\pm \mathrm{SE}(n=3)$. Values with different superscripts in the same column significantly differ at $P<0.05$.

Table 5. Aspartate transaminase (AST) levels in rat serum and tissues following exposure to various feed supplements

\begin{tabular}{lcccc}
\hline \multirow{2}{*}{ Group } & \multicolumn{4}{c}{ AST activity (U/I) in serum and tissues } \\
\cline { 2 - 5 } & serum & kidney & liver & heart \\
\hline 1 & $56.33 \pm 17.98^{\mathrm{a}}$ & $20.00 \pm 3.06^{\mathrm{a}}$ & $42.00 \pm 23.50^{\mathrm{a}}$ & $34.33 \pm 9.06^{\mathrm{a}}$ \\
2 & $76.67 \pm 7.54^{\mathrm{c}}$ & $16.67 \pm 10.27^{\mathrm{c}}$ & $65.00 \pm 13.58^{\mathrm{c}}$ & $43.00 \pm 23.07^{\mathrm{d}}$ \\
3 & $75.67 \pm 13.33^{\mathrm{c}}$ & $14.67 \pm 7.13^{\mathrm{c}}$ & $48.67 \pm 25.46^{\mathrm{b}}$ & $32.67 \pm 10.33^{\mathrm{b}}$ \\
4 & $60.00 \pm 7.51^{\mathrm{b}}$ & $23.67 \pm 9.21^{\mathrm{b}}$ & $89.00 \pm 0.00^{\mathrm{d}}$ & $38.00 \pm 12.77^{\mathrm{c}}$ \\
\hline
\end{tabular}

Group 1 = with soybean supplement; Group 2 = with fermented $J$. curcas supplement; Group 3 = with unfermented $J$. curcas supplement; Group $4=$ with fermented $J$. curcas and soybean supplements (1:1). Values are means $\pm \mathrm{SE}(n=3)$. Values with different superscripts in the same column significantly differ at $P<0.05$. 
Table 6. Alkaline phosphatase (ALP) levels in rat serum and tissues following exposure to various feed supplements

\begin{tabular}{lcccc}
\hline \multirow{2}{*}{ Group } & \multicolumn{4}{c}{ ALP activity (U/I) in serum and tissues } \\
\cline { 2 - 5 } & Serum & kidney & liver & heart \\
\hline 1 & $249.0 \pm 217.00^{\mathrm{a}}$ & $110.6 \pm 48.08^{\mathrm{a}}$ & $236.1 \pm 37.45^{\mathrm{a}}$ & $437.0 \pm 109.60^{\mathrm{a}}$ \\
2 & $277.5 \pm 72.65^{\mathrm{c}}$ & $104.2 \pm 37.49^{\mathrm{c}}$ & $337.6 \pm 170.60^{\mathrm{c}}$ & $680.5 \pm 262.10^{\mathrm{c}}$ \\
3 & $114.1 \pm 38.67^{\mathrm{b}}$ & $706.6 \pm 122.60^{\mathrm{b}}$ & $268.0 \pm 38.08^{\mathrm{b}}$ & $346.5 \pm 252.30^{\mathrm{b}}$ \\
4 & $272.6 \pm 195.40^{\mathrm{c}}$ & $103.7 \pm 93.45^{\mathrm{c}}$ & $507.8 \pm 45.23^{\mathrm{d}}$ & $879.2 \pm 439.90^{\mathrm{d}}$ \\
\hline
\end{tabular}

Group 1 = with soybean supplement; Group 2 = with fermented $J$. curcas supplement; Group 3 = with unfermented $J$. curcas supplement; Group $4=$ with fermented $J$. curcas and soybean supplements (1:1). Values are means $\pm \mathrm{SE}(n=3)$. Values with different superscripts in the same column significantly differ at $P<0.05$.

The rat serum levels of ALT were reduced significantly in the various treatment groups, relative to the control, while the levels of rat tissue ALT were altered inconsistently (Table 4). Furthermore, the $J$. curcas feeds elevated the level of rat serum AST, relative to the control but caused inconsistent differences in AST levels in rat tissues (Table 5). The feed supplemented with fermented $J$. curcas caused elevation $(P<0.05)$ of ALP levels in rat serum, liver and heart. Also the feed supplemented with soybean and fermented Jatropha increased $(P<0.05)$ the levels of ALP in rat serum, liver, and heart, relative to the control (Table 6).

\section{DISCUSSION}

The high nutritional value of the Jatropha seed cake is evident in the proximate composition of the various feeds tested in this experiment (Table 2). However, the death of a rat fed with the unfermented cake (group 3) in week 2 suggests that the cake is not safe for direct consumption until it is processed. Earlier findings have revealed that the Jatropha cake contains lethal levels of toxins (ADERIBIGBE et al. 1997; MAKKAR \& BECKER 1999) and hence the need for detoxification if the cake is to be used in feed formulations (BELEwU \& SAM 2010; BelewU et al. 2010).

Aspergillus niger was able to utilize the components of the Jatropha cake as a carbon source without supplementation, and in this process it either utilized some anti-nutrient factors and toxins, or was able to bio-convert them into innocuous substances. This may result from the impressive enzymatic capabilities of $A$. niger, which enable it to utilize a vast array of substrates and in the process convert them. The proximate composition of the various feeds shows that the protein content of group 2 feed, which contained fermented cake, was significantly higher (14.83\%) than those of the other feeds. This is consistent with the findings by BeLEwU \& SAM (2010), who reported a significantly higher protein content of the Jatropha cake fermented with $A$. niger. Relative to the control, the fermented J. curcas also had higher contents of moisture, protein, and fibre. However, when the soybean and the fermented J. curcas 
were combined equally as protein sources (group 4), the proximate analyses showed higher contents of moisture, protein, and fat over the individual supplements. This is consistent with the findings by MAKKAR \& BECKER (1999) that Jatropha cake contains more protein than soybeans. On the other hand, the higher protein content in group 2 feed could be due to the significant amounts of $A$. niger biomass produced, in addition to possible protein end-products of metabolism. This indicates that fermentation of $J$. curcas seed cake by $A$. niger may allow it to serve as an alternative protein source for animal feeds. Furthermore, the fermented $J$. curcas seed cake may be used in combination with other protein source supplements, in order to achieve higher or improved yield of animal feeds.

The various feeds were fed to animals also to determine their effects on growth and other biochemical parameters. We found that body weight generally did not differ significantly between the groups, but all rats put on weight in week 1 (Group 2 most strongly). The initial weight gain was followed by a slight decreasing trend in all groups in weeks 2-4, probably due to an adaptation mechanism. The alterations in average rat body and organ weights by the unfermented J. curcas (compared to the control and fermented $J$. curcas) may implicate the presence of anti-nutrients precipitating the weight loss. It has been reported that an increase or decrease in either absolute or relative weight of an organ after administering a chemical or drug is an indication of the toxic effect of that chemical (ORISAKWE et al. 2003). Administration of the aqueous extracts either individually or as a combination did alter the relative weights of heart, liver and kidney of the animals, as compared with controls. These results further reinforce the need for detoxification if $J$. curcas is to be used in animal feed formulation. Our data implied that the fermentation treatment of $J$. curcas may have detoxified and thus reduced the probable toxic effect the supplemented feed would have had if fed to the rats without fermentation or processing. This supports earlier observations by BELEWU \& SAM (2010) and BELEwU et al. (2010).

In order to assess the safety of the various feeds in rats, tissue marker enzymes ALT, AST, and ALP, all of which having a diagnostic value (ADEYEMI \& AKANJI 2010), were investigated. An increase or decrease in the levels of these enzymes, either in the serum or tissues (especially the liver), have been linked to various diseases or ingestion of toxic substances (Malomo et al. 1995; Malomo 2000; Adeyemi et al. 2012). The various supplemented feeds caused inconsistent alterations to the levels of rats' serum and tissue ALT, AST, and ALP relative to the control. The effect on the levels of ALT, AST, and ALP caused by the fermented or unfermented J. curcas supplemented feeds did not follow any definite trend. However, data on ALT levels were consistent with a previous report by BELEWU (2008). In contrast, data on AST levels differ from a previous report (ANNONGU et al. 2010), in which chemically extracted $J$. curcas supplemented feed lowered the level of rat serum AST. 


\section{CONCLUSIONS}

Our study shows that fermentation of $J$. curcas by $A$. niger has a potential to decrease the level of anti-nutrients, while optimizing the nutritional value of the seed cake for animal consumption. Our data have also demonstrated the potential of the fermented seed cake of $J$. curcas as an alternative protein source in animal feeds. Using fermented $J$. curcas instead of soybeans, groundnut, etc. in animal feeds may reduce the cost and boost animal production in developing countries.

Acknowledgements: We acknowledge the assistance of all the staff of both Microbiology and Biochemistry Departments during the conduct of this research and also Mr. Remi for kindly supplying us with the Jatropha seeds.

Conflict of interest: We declare no competing interests.

\section{REFERENCES}

Aderibigbe A. O., Johnson C., Makka H. P. S., Becker K., Folldi N. 1997. Chemical composition and effect of heat on organic matter and nitrogen degradability and some antinutritional components of Jatropha meal. Animal Feed Sci. Techn. 67: 223-243.

Adeyemi O. S., Akanji M. A. 2010. Biochemical changes in the kidney and liver of rats following administration of ethanolic extract of Psidium guajava leaves. Hum. Exp. Toxicol. 30: $1266-1274$.

Adeyemi O. S., Fambegbe M., Daniyan O. R., Nwajei I. 2012. Yoyo Bitters, a polyherbal formulation influenced some biochemical parameters in Wistar rats. J. Basic Clin. Physiol. Pharmacol. 23: 135-138.

Annongu A. A., Joseph J. K., Apata D. F., Adeyina A O., Yousuf M. B., Ogunjimi K. B. 2010. Detoxification of Jatropha curcas seeds for use in nutrition of monogastric livestock as alternative feedstuff. Pak. J. Nutr. 9: 902-904.

AOAC - Association Of Official Analytical Chemists 1995. Official methods of analysis. Association of Official Analytical Chemists. 15th edition. Washington DC.

Belewu M. A. 2008. Replacement of fungus treated Jatropha curcas kernel meal in the diet of rat. Green Farming J. 2: 154-157.

Belewu M. A., Belewu K. Y., Badmos A. H. A., Damisa H. 2009a. Performance of West African dwarf goat fed on cellophone recharge cards treated with Trichoderma harzanium. J. Anim. Plant Sci. 2: 170-173.

Belewu M. A., Belewu K. Y., Ogunsola F. O. 2010. Nutritive value of dietary fungi treated Jatropha curcas kernel cake: voluntary intake, growth and digestibility coefficient of goat. Agric. Biol. J. N. Am. 1: 135-138.

Belewu M. A., Muhammed N. O., Ajayi F. T., Abdulgafar D. T. 2009b. Performance characteristics of goat fed Trichoderma treated feather meal-rice husk mixture. Animal Nutr. Feed Techn. 9: 203-208.

Belewu M. A., SAm R. 2010. Solid state fermentation of Jatropha curcas kernel cake: Proximate composition and antinutritional components. J. Yeast Fungal Res. 1: 44-46.

Devendra D., Liu E., Eisenbarth G. S. 2004. Type 1 diabetes: recent developments. BMJ 328 : $750-754$.

Fawole M. O., Oso B. O. 1995. Laboratory manual on microbiology 2nd edn. Spectrum Books Ltd., Ibadan, Nigeria. 
Gallegos-Tintoré S., Torres-Fuentes C., Martínez-Ayala A. L., Solorza-Feria J., Alaiz M., Girón-Calle J., Vioque J. 2011. Antioxidant and chelating activity of Jatropha curcas L. protein hydrolysates. J Sci Food Agric 91: 1618-1624.

Makkar H. P. S., Becker K. 1999. Potential of $J$. curcas seed meal as a protein supplement to livestock feed, constraints to its utilization and possible strategy to overcome constraints. In: Biofuel and Industrial Products from Jatropha curcas, Proceedings of the Symposium "Jatropha97” (Gubitz G. M., Mittelbachand M., Trabi M., Eds.), Feburary 23-27, 1997, Managua, Nicaragua, pp. 190-205.

Makkar H. P .S., Becker K., Schmook B. 1998. Edible provenances of Jatropha curcas from Quintana Roo state of Mexico and effect of roasting on antinutrient and toxic factors in seeds. Plant Foods Hum. Nut. 52: 31-36.

Makkar H. P. S., Becker K., Sporer F., Wink M. 1997. Studies on Nutritive potential and toxic constituents of different provenances of Jatropha curcas. J. Agric. Food Chem. 45: 3152-3157.

Malomo S. O. 2000. Toxicological implications of Ceftriaxine $\left(\right.$ Rocephin $\left.^{\mathrm{TM}}\right)$ administration in rats. Niger. J. Biochem. Mol. Biol. 15: 33-38.

Malomo S. O., Daramola A. S., Balogun E. A. 1995. Some serum and tissue enzyme changes in mice infected with Plasmodium yoelii nigeriensis before and after administration of halofantrine hydrochloride. Niger. J. Biochem. Mol. Biol. 10: 71-77.

Orisakwe O. E., Hussaini D. C., Afonne O. J. 2003. Testicular effects of sub-chronic administration of Hibiscus sabdariffa calyx aqueous extract in rats. Reprod. Toxicol. 18: 295-298.

Peace O. E., Aladesanmi A. O. 2008. Effect of fermentation on some chemical and nutritive properties of Berlander Nettle spurge (Jatropha cathartica) and Physic nut (Jatropha curcas) seeds. Pakistan J. Nutrition 7: 292-296.

REC GSCC 1972. Optimised standard colorimetric methods. Serum alkaline phosphatase (DGKC). J. Clin. Chem. Clin. Biochem. 10: 182-182.

Reitman S., Frankel S. 1957. A colourimetric method for the determination of Serum glutamicoxaloacetic and glutamic-pyruvic transaminase. Am. J. Clin. Pathol. 28: 56-61.

Schмidt E., SснміDт F.W. 1963. Determination of serum GOT and GPT. Enzyme. Biol. Clin. 3: 1-5. 